\title{
The effects of austerity measures on quality of healthcare services: a national survey of physicians in the public and private sectors in Portugal
}

Tiago Correia ${ }^{* *}$, Graça Carapinheiro ${ }^{1}$, Helena Carvalho ${ }^{1}$, José Manuel Silva ${ }^{2}$ and Gilles Dussault ${ }^{3}$

\begin{abstract}
Background: The European Union member countries reacted differently to the 2008 economic and financial crisis. However, few countries have monitored the outcomes of their policy responses, and there is therefore little evidence as to whether or not savings undermined the performance of health systems. We discuss the situation in Portugal, where a financial adjustment program was implemented between 2011 and 2014, and explore the views of health workers on the effects of austerity measures on quality of care delivery.

Methods: A nationwide survey of physicians' experiences was conducted in 2013-2014 ( $n=3442)$. We used a two-step model to compare public and private services and look at the possible moderating effects of the physicians' specialty and years of practice. Our data analysis included descriptive statistics, the independent $t$ test, analysis of variance (ANOVA), multivariate logistic regression, General Linear Model Univariate Analysis, non-parametric methods (bootstrap), and post hoc probing.

Results: Mainly in the public sector, the policy goal of maintaining quality of care was undermined by a lack of resources, the deterioration in medical residency conditions, and to a lesser extent, greater administrative interference in clinical decision-making. Differences in public and private services showed that the effects of the austerity measures were not the same throughout the health system. Our results also showed that physicians with similar years of practice and in the same medical specialty did not necessarily experience the same pressures.

Conclusions: The debate on the effects of austerity measures should focus more closely on health workers' concrete experiences, as they demonstrate the non-linearity between policy setting and expected outcomes. We also suggest that it is necessary to explore the interplay between lower quality and the undermining of trust relationships in health.
\end{abstract}

Keywords: Portugal, Economic crisis, Adjustment programs, Austerity measures, Quality of care, Trust

\section{Background}

Crises and health system performance: where do we stand in the debate?

How health services are planned, purchased, and delivered has a direct impact on the key dimensions of health system performance, i.e., efficiency, quality, and access [1]. In the aftermath of the economic and financial crisis that hit most member countries of the European Union,

\footnotetext{
* Correspondence: tiago.correia@iscte-iul.pt

${ }^{1}$ School of Sociology and Public Policies, ISCTE-Instituto Universitário de

Lisboa, Av Forcas Armadas, 1649-026 Lisbon, Portugal

Full list of author information is available at the end of the article
}

the question is raised of whether the impact of cuts in public funding and other austerity measures had neutral effects or have undermined the performance of health services [2].

As the crisis grew in intensity, the WHO Regional Office for Europe [3] recommended that member states monitor the effects of their policy responses on health indicators. Few countries did so, and existing assessments have focused mainly on measuring changes in access and efficiency, thus the need for further evidence on the dimension of quality of care delivery [4]. 
The analysis of health services delivery needs to take into account that the operation of provider organizations is more complex than assumed by political decisionmakers [5]. This premise is based on the neoinstitutional literature that argues that macro-level policies are affected by workplace-level contingencies that produce "perverse or non-expected" effects [6, 7].

This has received little attention in the debates on the effects on the quality of health services of political responses to the crisis. This paper is a contribution to the debate through a deeper look at how different levels of care, e.g., hospital and primary care, and the internal stratification of the medical profession, e.g., by specialty and years of service, constitute such contingencies [8-10]. That may explain why various categories of physicians, working in different environments, have reacted differently to the pressures generated by policy responses to the crisis.

Additionally, although public services have been the main target of austerity measures, complementarity with the private sector and growing pressure for marketization in many countries [11] raises the issue of understanding better how private providers have adapted to the economic crisis. There has not yet been systematic research into this matter even though some authors suggest that public regulation can be less effective in monitoring and penalizing for-profit investors for patient selection [12].

\section{The situation in Portugal}

In 2011, a Memorandum of Understanding (MoU) between the Portuguese Government and the International Monetary Fund, The European Central Bank, and the European Commission designed a $€ 78$ billion, 3-year financial adjustment program with specific timelines and policy targets to reduce the budget deficit from 9.8 to 3\% of GDP in 2013. Cost containment in the health sector was considered feasible without undermining the quality of services [13]. Direct cuts in the health sector were initially estimated at $€ 550$ million. However, they doubled after 1 year and reached $€ 1.3$ billion in 2013 [14].

Specific health-related policies were aimed at different targets: more cost-sharing, better drug-market regulation, tighter control over physicians' prescribing and of the management of public provider organizations, more transparent public-private partnership, expansion of primary health care services, and savings on workforce costs. Table 1 shows the extent to which these objectives were achieved.

Overall, the massive reduction in public expenditure came more from cost-sharing, tighter drug-market regulation, control over prescribing, and of the management of provider organizations. Improvements in publicprivate partnership, better access to primary healthcare, and workforce changes contributed to a lesser extent. Available studies of the effects of those reductions have focused mainly on efficiency and access [15] and planning and purchasing of services $[16,17]$.

\section{Objectives of the study}

The aim of this research is to provide more evidence about the effects of an adjustment program on the quality of healthcare. Its contribution to the debate is threefold. First, quality needs to be considered as important as efficiency and access. Second, it highlights to what extent an analysis of delivery of healthcare requires looking at different sources of information than those on planning and purchasing of services. Health workers' daily experiences are a rich source of information in this regard [18]. Third, it presents comparisons between and within the public and private sectors, a neglected aspect in research on policy responses to economic crises in Europe.

\section{Methods}

\section{Study design and participants}

A two-step model (Fig. 1) was designed to describe the experiences of physicians working in public and private services (main-effect model) and analyze variations between the two groups based on years of experience and specialty (model with moderated effects). All types of public providers were included in the public sector, as were for-profit and professional-based insurers in the private sector.

Data was collected in a national survey asking physicians about their experiences after 2011, when the financial adjustment program began. A structured, self-administered questionnaire was sent by post from May 2013 to January 2014 to all physicians registered with the Portuguese Medical Council $(N=43,874)$. The key aim was to reach as many physicians as possible with no previous criteria underpinning the selection of cases. A total of 3442 questionnaires from physicians practicing in Portugal at that time were returned and validated through consistency and readability analysis. Even though it is one of the largest national-level databases of physicians in Europe, it was not possible to define a probabilistic sample of practicing physicians in Portugal because (i) there are no standardized data on the number of doctors who have retired or emigrated or on their distribution by sector or type of medical services and (ii) confidentiality criteria imposed by the Medical Council's ethics committee prevented us from collecting the respondents' age or geographical location.

\section{Measures \\ Dependent variables}

Quality of care is analyzed in different ways depending on disciplinary backgrounds [19]. The analysis adopted here lay in a structure-process link, as it was intended to ascertain whether reforms changed how care was actually delivered [20]. Given that the questionnaire was sent 
Table 1 Implementation of the MoU in Portugal 2011-2014

\begin{tabular}{|c|c|c|c|c|c|}
\hline & & \multicolumn{4}{|l|}{ Policy outcome } \\
\hline & & Accomplished & $\begin{array}{l}\text { Partially } \\
\text { accomplished }\end{array}$ & $\begin{array}{l}\text { Not } \\
\text { accomplished }\end{array}$ & $\begin{array}{l}\text { Withdrawn/ } \\
\text { omitted }\end{array}$ \\
\hline \multirow[t]{6}{*}{ Cost sharing } & Review and increase patient fees & $x$ & & & \\
\hline & Reduction of exemption categories & $x$ & & & \\
\hline & Increase inflation-indexed fees & $x$ & & & \\
\hline & $\begin{array}{l}\text { Cut tax allowances for healthcare, including private } \\
\text { insurance }\end{array}$ & $x$ & & & \\
\hline & $\begin{array}{l}\text { Reduce the cost of health benefits schemes for public } \\
\text { servants }\end{array}$ & $x$ & & & \\
\hline & Reduce costs for patient transportation & $x$ & & & \\
\hline \multirow{10}{*}{$\begin{array}{l}\text { Regulation of the drug } \\
\text { market }\end{array}$} & Control retail price & $x$ & & & \\
\hline & Move the responsibility of pricing to the Ministry of Health & $x$ & & & \\
\hline & Revise the international reference-pricing system & $x$ & & & \\
\hline & Monitor expenditure monthly and limit public spending & $x$ & & & \\
\hline & Remove barriers to generic medicines & $x$ & & & \\
\hline & Change the calculation of pharmacies' profit margin & $x$ & & & \\
\hline & Gradually increase the share of generic medicines & $x$ & & & \\
\hline & $\begin{array}{l}\text { Implement existing legislation on the regulation of } \\
\text { pharmacies }\end{array}$ & & & & $x$ \\
\hline & Speed up the reimbursement of generics & & & & $x$ \\
\hline & Introduce a contribution paid by pharmacies & & & & $x$ \\
\hline \multirow[t]{4}{*}{$\begin{array}{l}\text { Control of doctors' } \\
\text { prescription }\end{array}$} & $\begin{array}{l}\text { Make electronic prescription of medicines and diagnostic } \\
\text { tests covered by public reimbursement fully compulsory } \\
\text { for physicians (public and private sectors) }\end{array}$ & $x$ & & & \\
\hline & $\begin{array}{l}\text { Encourage physicians to prescribe generic medicines and } \\
\text { less costly branded products (public and private sectors) }\end{array}$ & $x$ & & & \\
\hline & $\begin{array}{l}\text { Introduce international prescription guidelines for drugs, } \\
\text { exams and treatment }\end{array}$ & $x$ & & & \\
\hline & $\begin{array}{l}\text { Improve monitoring of prescription of medicines and } \\
\text { diagnostic services and impose systematic assessments } \\
\text { by each doctor of quantity and cost. Introduce sanctions } \\
\text { and penalties }\end{array}$ & & $x$ & & \\
\hline \multirow{11}{*}{$\begin{array}{l}\text { Control of operating } \\
\text { costs and performance } \\
\text { in the NHS }\end{array}$} & $\begin{array}{l}\text { Legislative and administrative framework for a centralized } \\
\text { procurement system for the purchase of medical goods }\end{array}$ & $x$ & & & \\
\hline & $\begin{array}{l}\text { Change in the existing accounting framework in hospitals SOEs } \\
\text { to that of private companies and other SOEs }\end{array}$ & $x$ & & & \\
\hline & Concentration and rationalization of non-hospital care provision & $x$ & & & \\
\hline & Concentration and rationalization of the hospital network & $x$ & & & \\
\hline & $\begin{array}{l}\text { Continued publication of clinical guidelines and introduction of } \\
\text { an auditing system }\end{array}$ & $x$ & & & \\
\hline & Benchmarking of hospital performance & $x$ & & & \\
\hline & Interoperability of IT systems in hospitals & $x$ & & & \\
\hline & $\begin{array}{l}\text { Finalization and regular updates of uniform coding system for } \\
\text { medical supplies }\end{array}$ & & $x$ & & \\
\hline & $\begin{array}{l}\text { Implement the centralized purchasing of medical goods using } \\
\text { the uniform coding system }\end{array}$ & & $x$ & & \\
\hline & $\begin{array}{l}\text { Clearing of existing arrears in the hospital sector and prevention } \\
\text { of accumulation of new arrears }\end{array}$ & & $x$ & & \\
\hline & Completion of patient electronic medical records & & & $\mathrm{x}$ & \\
\hline
\end{tabular}


Table 1 Implementation of the MoU in Portugal 2011-2014 (Continued)

\begin{tabular}{|c|c|c|c|c|c|c|}
\hline & & & \multicolumn{4}{|l|}{ Policy outcome } \\
\hline & & & Accomplished & $\begin{array}{l}\text { Partially } \\
\text { accomplished }\end{array}$ & $\begin{array}{l}\text { Not } \\
\text { accomplished }\end{array}$ & $\begin{array}{l}\text { Withdrawn/ } \\
\text { omitted }\end{array}$ \\
\hline \multirow[t]{4}{*}{$\begin{array}{l}\text { Public-private } \\
\text { relationship }\end{array}$} & \multicolumn{2}{|c|}{$\begin{array}{l}\text { Increase in competition between private providers and } \\
\text { reduction in NHS payment of exams and treatments }\end{array}$} & $x$ & & & \\
\hline & \multicolumn{2}{|c|}{ Centralized monitoring of public-private partnership contracts } & $x$ & & & \\
\hline & \multicolumn{2}{|c|}{$\begin{array}{l}\text { Regular revision of fees paid by the NHS for exams and } \\
\text { treatment by private providers }\end{array}$} & & & & $x$ \\
\hline & \multicolumn{2}{|c|}{$\begin{array}{l}\text { Assessment of compliance with European competition rules } \\
\text { for the provision of services in the private healthcare sector }\end{array}$} & & & & $x$ \\
\hline \multirow[t]{5}{*}{ Access to healthcare } & \multirow{4}{*}{$\begin{array}{l}\text { Reinforce } \\
\text { primary health } \\
\text { care }\end{array}$} & $\begin{array}{l}\text { Increase the number of patients per primary } \\
\text { care unit/family doctor }\end{array}$ & $x$ & & & \\
\hline & & $\begin{array}{l}\text { Increase the number of primary care units } \\
\text { using salary and performance-related } \\
\text { payments }\end{array}$ & & $x$ & & \\
\hline & & $\begin{array}{l}\text { Separate HR from hospitals and reconsider } \\
\text { the role of nurses and other professionals }\end{array}$ & & & $x$ & \\
\hline & & Review geographical distribution of GPs & & & $x$ & \\
\hline & \multicolumn{2}{|c|}{ Move hospital outpatient services to primary care units } & & & $x$ & \\
\hline \multirow[t]{5}{*}{ Workforce } & \multicolumn{2}{|c|}{$\begin{array}{l}\text { Update working time, increase mobility, adopt flexible time } \\
\text { arrangements and review payment mechanisms }\end{array}$} & $x$ & & & \\
\hline & \multicolumn{2}{|c|}{ Conduct an annual inventory of doctors } & $x$ & & & \\
\hline & \multicolumn{2}{|c|}{ Make human resource allocation plans } & & & $x$ & \\
\hline & \multicolumn{2}{|c|}{$\begin{array}{l}\text { Increase mobility of healthcare staff within and between } \\
\text { regions }\end{array}$} & & & $x$ & \\
\hline & \multicolumn{2}{|c|}{$\begin{array}{l}\text { Ensure transparent selection of the chairs and members } \\
\text { of hospital boards }\end{array}$} & & & & $x$ \\
\hline
\end{tabular}

Legend: Own elaboration from $[26,27]$

to all registered physicians, we had to find suitable ways of comparing people in different positions and workplace settings. Therefore, the structure-process analysis was empirically driven according to the implementation of the MoU in Portugal from 2011 to 2014. Quality of care was addressed in terms of changes physicians said they had experienced in three key aspects of their daily

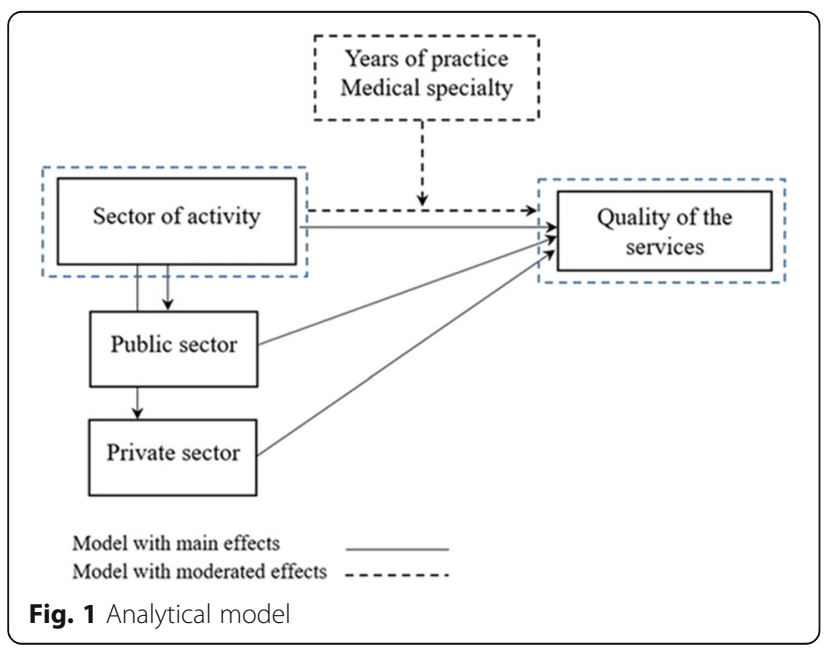

practice: control of prescriptions, operating costs, and performance, as detailed in Table 1 . Six dependent variables (DVs) were defined as follows:

-Administrative interference in decision making, i.e., less autonomy in physicians' decision-making in favor of organizational control: more rejections of innovative treatments (DV1), pressure to choose cheaper treatments exerted by the administration (DV4), and pressure not to prescribe certain drugs exerted by the administration (DV5)

-Insufficient resources, i.e., possible limitation of material resources for the provision of care: regular shortages of supplies (gloves, masks, needles, etc.) (DV2) and regular shortages of drugs (DV3) -Deterioration in medical residency, i.e., organizational changes that directly affected physicians' advanced training: less favorable conditions for medical residencies (DV6) (e.g., overworked residents and less time for tutors' work)

The list of questions was preceded by: "Based on your personal experience and in comparison to 2011", and dichotomous dummy variables were defined with the 
answer "no" as a reference category (0). The proportion of "yes" answers was also used to make group comparisons.

\section{Independent variables}

The sector was analyzed at two levels: physicians working exclusively for the National Health Service (NHS) or exclusively in the private sector. The NHS included hospitals and primary health care and the private sector included small offices, clinics, and private hospitals.

\section{Moderator variables}

Years of practice meant the length of time physicians had been registered with the Medical Council (a compulsory requirement after post-graduate medical training). They were measured in months as a quantitative variable.

The 21 selected medical specialties (of a total of 41) were those of physicians working exclusively in the NHS or exclusively in the private sector. These were combined as follows: anesthesiology, cardiology, dermatology, gastroenterology, general practice/family medicine, general surgery, internal medicine, neurology, obstetrics and gynecology, oncology (medical and radiation oncology), ophthalmology, orthopedics, other surgical specialties (angiology and vascular, cardiothoracic, maxillofacial, pediatric surgery and plastic and reconstructive surgery, neurosurgery, and urology), ENT, pediatrics, physical medicine and rehabilitation, psychiatry, public health, pulmonology, radiology (nuclear medicine, neuroradiology, and radiology), and stomatology.

\section{Data analysis}

Descriptive statistical analysis was used to examine the distribution of the variables, including non-answers. The independent $t$ test and analysis of variance (ANOVA) were used to examine group differences on the basis of the proportion of "yes" answers for each dependent variable. A multivariate logistic regression was conducted to evaluate the moderator effect of years of practice and medical specialty in the relationship between sector of activity and quality of care using the Process Macro [21]. A General Linear Model (GLM) Univariate Analysis was conducted to assess the moderator effect of medical specialty testing interaction effects. Since some of the combinations of the factorial design showed a small number of cases, a non-parametric method (bootstrap) was also used to validate the results obtained by the parametric procedure. Some of the initial medical specialties had to be excluded in order to avoid empty combinations in the factorial design. Post hoc probing was conducted to interpret significant interactions utilizing estimates obtained from the fitted models [22] and also to achieve plotting interactions. All analyses were conducted using SPSS (version 23).

\section{Results}

\section{Descriptive statistics}

The final sample comprised 2063 physicians who had valid data according to the main inclusion criteria, working exclusively in the public or private sector (Table 2). Most respondents were general practitioners and working exclusively in the public sector. The percentage of younger doctors was slightly higher. As regards dependent variables, results were as follows: $17.3 \%$ reported more refusals of innovative treatments, $64.9 \%$ regular shortages of supplies, 30.6\% regular shortages of drugs, $23.8 \%$ greater pressure to choose less costly treatments, $15.6 \%$ greater pressure to limit the prescription of certain drugs, and $48.9 \%$ less favorable conditions for medical residencies (Table 2).

\section{Group comparisons}

A comparison of means between sectors showed that they significantly affected physicians' evaluation of quality of care in several indicators: usual shortage of supplies $(t(1054)=14.379, p<.001)$ (DV2), shortage of drugs $(t \quad(938)=4.809, p<.001) \quad(\mathrm{DV} 3)$, pressure to choose cheaper treatments $(t(1049)=3.001, p=.003)$ (DV4), pressure to limit the prescription of certain drugs $(t(1276)=6.044, p<.001)$ (DV5), and less favorable conditions for medical residencies $(t(684)=-2.439$, $p=.015$ ) (DV6). Except for the latter, there were more "yes" answers among physicians working exclusively in the public sector (see 1st step, Table 3).

Significant differences were found among physicians working exclusively at public hospitals and in primary care in all dependent variables $(p<.05)$. Physicians working exclusively in public hospitals mentioned refusal of innovative treatments $(t(786)=-6.663, p<.001)(\mathrm{DV} 1)$, drug shortages $(t(751)=-10.914, p<.001)(\mathrm{DV} 3)$ and, with a smaller difference, less favorable conditions for medical residencies $(t(554)=-1.996, p=.023)$ (DV6). Physicians working in primary care services mentioned shortages of equipment $(t(815)=6.893, p<.001)(\mathrm{DV} 2)$, pressure to choose cheaper treatments $(t(820)=4.869$, $p<.001)$ (DV4), and pressure not to prescribe certain drugs $(t(910)=4.741, p<.001)($ DV5).

Significant differences were found among physicians working in the private sector only regarding refusal of innovative treatments $(F(2,116)=3.682, p=.028)(\mathrm{DV} 1)$ and, to a lesser extent, less favorable conditions for medical residencies $(F(2,48)=3.299, p=.045)$ (DV6). There were fewer "yes" answers in both indicators among physicians working in clinics (see 1nd step, Table 3).

\section{Moderator analysis}

A moderator effect of years of practice was tested to provide a more detailed understanding of the differences between working in the public or private sector (Fig. 1). 
Table 2 Descriptive statistics

\begin{tabular}{|c|c|c|c|c|c|}
\hline \multicolumn{4}{|c|}{ Analyses variables and categories } & \multirow{2}{*}{$\frac{N}{1209}$} & \multirow{2}{*}{$\frac{\%}{58.6}$} \\
\hline \multirow{12}{*}{$\begin{array}{l}\text { Independent } \\
\text { variable }\end{array}$} & \multirow{12}{*}{$\begin{array}{l}\text { Sector of } \\
\text { activity }\end{array}$} & \multicolumn{2}{|c|}{ Exclusive in public } & & \\
\hline & & \multicolumn{2}{|c|}{ Exclusive in private } & 854 & 41.4 \\
\hline & & \multicolumn{2}{|l|}{ Total } & 2063 & 100.0 \\
\hline & & \multirow[t]{3}{*}{$\begin{array}{l}\text { Exclusive } \\
\text { in public }\end{array}$} & $\begin{array}{l}\text { Primary } \\
\text { healthcare }\end{array}$ & 509 & 42.1 \\
\hline & & & $\begin{array}{l}\text { Public } \\
\text { hospitals }\end{array}$ & 634 & 52.4 \\
\hline & & & $\begin{array}{l}\text { Non } \\
\text { answer }\end{array}$ & 66 & 5.5 \\
\hline & & \multicolumn{2}{|l|}{ Total } & 1209 & 100.0 \\
\hline & & \multirow[t]{4}{*}{$\begin{array}{l}\text { Exclusive } \\
\text { in private }\end{array}$} & $\begin{array}{l}\text { Small-size } \\
\text { offices }\end{array}$ & 274 & 32.1 \\
\hline & & & Clinics & 230 & 26.9 \\
\hline & & & Hospital & 79 & 9.3 \\
\hline & & & $\begin{array}{l}\text { Non } \\
\text { answer }\end{array}$ & 271 & 31.7 \\
\hline & & \multicolumn{2}{|l|}{ Total } & 854 & 100.0 \\
\hline \multirow{26}{*}{$\begin{array}{l}\text { Moderator } \\
\text { variables }\end{array}$} & \multirow{5}{*}{$\begin{array}{l}\text { Years of } \\
\text { practice }\end{array}$} & \multicolumn{2}{|c|}{ Up to 12 years } & 644 & 31.2 \\
\hline & & \multicolumn{2}{|c|}{$13-25$ years } & 473 & 22.9 \\
\hline & & \multicolumn{2}{|c|}{ 26-39 years } & 520 & 25.2 \\
\hline & & \multicolumn{2}{|c|}{ Over 40 years } & 426 & 20.0 \\
\hline & & \multicolumn{2}{|l|}{ Total } & 2063 & 100.0 \\
\hline & \multirow{21}{*}{$\begin{array}{l}\text { Medical } \\
\text { specialty }\end{array}$} & \multicolumn{2}{|c|}{ Anesthesiology } & 59 & 2.9 \\
\hline & & \multicolumn{2}{|c|}{ Cardiology } & 28 & 1.4 \\
\hline & & \multicolumn{2}{|c|}{ Dermatology } & 17 & .8 \\
\hline & & \multicolumn{2}{|c|}{ Gastroenterology } & 23 & 1.1 \\
\hline & & \multicolumn{2}{|c|}{$\begin{array}{l}\text { General practice/ } \\
\text { family medicine }\end{array}$} & 498 & 24.1 \\
\hline & & \multicolumn{2}{|c|}{ General surgery } & 110 & 5.3 \\
\hline & & \multicolumn{2}{|c|}{ Internal medicine } & 132 & 6.4 \\
\hline & & Neurology & & 16 & .8 \\
\hline & & $\begin{array}{l}\text { Obstetrics } \\
\text { gynecolos }\end{array}$ & $\begin{array}{l}\text { and } \\
\text { gy }\end{array}$ & 78 & 3.8 \\
\hline & & Oncology & & 38 & 1.8 \\
\hline & & Ophthalm & ology & 41 & 2.0 \\
\hline & & Orthopedi & & 49 & 2.4 \\
\hline & & $\begin{array}{l}\text { Other surc } \\
\text { specialties }\end{array}$ & yical & 54 & 2.6 \\
\hline & & Otorhinola & aryngology & 29 & 1.4 \\
\hline & & Pediatrics & & 109 & 5.3 \\
\hline & & $\begin{array}{l}\text { Physical } m \\
\text { and rehab }\end{array}$ & $\begin{array}{l}\text { hedicine } \\
\text { ilitation }\end{array}$ & 26 & 1.3 \\
\hline & & Psychiatry & & 64 & 3.1 \\
\hline & & Public Hea & alth & 28 & 1.4 \\
\hline & & Pulmonol & gy & 31 & 1.5 \\
\hline & & Radiology & & 36 & 1.7 \\
\hline & & Stomatolo & & 30 & 1.5 \\
\hline
\end{tabular}

Table 2 Descriptive statistics (Continued)

\begin{tabular}{|c|c|c|c|c|}
\hline \multicolumn{3}{|c|}{ Analyses variables and categories } & \multirow{2}{*}{$\frac{N}{567}$} & \multirow{2}{*}{$\frac{\%}{27.5}$} \\
\hline & & Non answer & & \\
\hline & & Total & 2063 & 100.0 \\
\hline \multirow{18}{*}{$\begin{array}{l}\text { Dependent } \\
\text { variables-quality } \\
\text { of care }\end{array}$} & \multirow[t]{3}{*}{ DV1 } & No & 1465 & 82.7 \\
\hline & & Yes & 307 & 17.3 \\
\hline & & Total & 1772 & 100.0 \\
\hline & \multirow[t]{3}{*}{ DV2 } & No & 639 & 35.1 \\
\hline & & Yes & 1184 & 64.9 \\
\hline & & Total & 1823 & 100.0 \\
\hline & \multirow[t]{3}{*}{ DV3 } & No & 1149 & 69.4 \\
\hline & & Yes & 506 & 30.6 \\
\hline & & Total & 1655 & 100.0 \\
\hline & \multirow[t]{3}{*}{ DV4 } & No & 1384 & 76.2 \\
\hline & & Yes & 432 & 23.8 \\
\hline & & Total & 1816 & 100.0 \\
\hline & \multirow[t]{3}{*}{ DV5 } & No & 1819 & 84.4 \\
\hline & & Yes & 336 & 15.6 \\
\hline & & Total & 2155 & 100.0 \\
\hline & \multirow[t]{3}{*}{ DV6 } & No & 747 & 51.1 \\
\hline & & Yes & 716 & 48.9 \\
\hline & & Total & 1463 & 100.0 \\
\hline
\end{tabular}

Notes: (1) Sums of subject numbers for the dependent variables are not always equal because of missing data; percentages are based on number of subjects for whom data were available; (2) DV1 - refusal of innovative treatments; DV2-regular shortage of work supplies; DV3—shortage of drugs; DV4-pressure to choose less-expensive treatments; DV5—-pressure not to prescribe specific drugs; DV6-inferior medical training

The interaction effect between sector and years of practice had a significant effect on refusal of innovative treatments $(B=-0.005, Z=-2.396, p=.017,95 \%$ $\mathrm{CI}=-0.008,-0.001)$ (DV1), pressure not to prescribe certain drugs $(B=0.005, Z=2.884, p=.004,95 \% \mathrm{CI}=0.002$, 0.009 ) (DV5) and less favorable conditions for medical residencies $(B=-0.004, \quad Z=-2.075, \quad p=.038, \quad 95 \%$ $\mathrm{CI}=-0.007,-0.001)(\mathrm{DV} 6)$ (Table 4$)$.

Figure 2 shows that refusal of innovative treatments tended to be reported more by older physicians in the private sector and younger physicians in the public sector. Post hoc tests revealed a significant effect of years of practice only in the public sector $(B=-0.003, Z=-3.941, p=.000,95 \%$ $\mathrm{CI}=-0.004,-0.001)$.

As presented in Fig. 3, the pressure not to prescribe certain drugs was not affected by years of practice in the public sector $(p>.05)$. A significant negative effect was found in the private sector and was less likely to occur among older physicians $(B=-0.006, Z=-3.121, p=.002$, 95\% CI $=-0.009,-0.002$ ) (Fig. 3).

In contrast, less favorable conditions for medical residencies were not affected by years of practice in the private sector $(p>.05)$, while a significant negative effect was observed 
Table 3 Comparisons of quality of care between groups (t-test and one-way ANOVA)

\begin{tabular}{|c|c|c|c|c|c|c|c|}
\hline \multirow{2}{*}{\multicolumn{2}{|c|}{ Sector of activity }} & DV1 & DV2 & DV3 & DV4 & DV5 & DV6 \\
\hline & & Mean $^{\mathrm{a}}$ & Mean & Mean & Mean & Mean & Mean \\
\hline \multicolumn{8}{|l|}{ 1st step } \\
\hline \multicolumn{2}{|l|}{ Public } & 0.153 & 0.731 & 0.300 & 0.262 & 0.200 & 0.435 \\
\hline \multicolumn{2}{|l|}{ Private } & 0.134 & 0.228 & 0.110 & 0.158 & 0.058 & 0.571 \\
\hline \multicolumn{2}{|c|}{ Model test } & $t(1026)=0.683$ & $t(1054)=14.379^{* * *}$ & $t(938)=4.809^{* * *}$ & $t(1049)=3.001^{* *}$ & $t(1276)=6.044^{* * *}$ & $t(684)=-2.436^{*}$ \\
\hline \multicolumn{8}{|l|}{ 2nd step } \\
\hline \multirow[t]{2}{*}{ Public } & $\begin{array}{l}\text { Primary } \\
\text { healthcare }\end{array}$ & 0.065 & 0.847 & 0.091 & 0.351 & 0.267 & 0.385 \\
\hline & Public hospitals & 0.234 & 0.637 & 0.437 & 0.201 & 0.143 & 0.471 \\
\hline \multicolumn{2}{|c|}{ Model test } & $t(786)=-6.663^{* * *}$ & $t(815)=6.893^{* * *}$ & $t(751)=-10.914^{* * *}$ & $t(820)=4.869^{* * *}$ & $t(910)=4.741^{* * *}$ & $t(554)=-1.996^{*}$ \\
\hline \multirow[t]{3}{*}{ Private } & Small-size offices & 0.286 & 0.125 & 0.100 & 0.161 & 0.056 & 0.636 \\
\hline & Clinics & 0.074 & 0.333 & 0.129 & 0.239 & 0.061 & 0.308 \\
\hline & Hospital & 0.167 & 0.188 & 0.133 & 0.194 & 0.100 & 0.750 \\
\hline \multicolumn{2}{|c|}{ Model test } & $F(2,116)=3.682^{*}$ & $F(2,115)=2.768$ & $F(2,78)=0.0660$ & $F(2,105)=1.609$ & $F(2,201)=0.514$ & $F(2,48)=3.299^{*}$ \\
\hline
\end{tabular}

${ }^{a}$ Mean = proportion of answer "yes"

${ }^{*} p<.05 ;{ }^{* *} p<.01 ;{ }^{* * *} p<.001$

in the public sector $(B=-0.003, Z=-4.219, p<.001,95 \%$ $\mathrm{CI}=-0.005,-0.002)$ (Fig. 4).

Regarding regular shortages of supplies and drugs, only the main effect was significant, as years of practice did not have a moderating effect $(p<.05)$ (Table 4$)$. Older physicians made less mention of regular shortages of supplies in both the private and public sectors $(B=-0.003$, $Z=-2.594, p=.01,95 \% \mathrm{CI}=-0.006,-0.001$ and $B=-$ $0.002, Z=-3.238, p=.001,95 \% \mathrm{CI}=-0.003,-0.001$, respectively). Drug shortages also produced fewer "yes" answers from older physicians and this significant effect occurred in both sectors $(B=-0.005, Z=-2.622, p=.009$,
95\% CI $=-0.008,-0.001$ and $B=-0.003, Z=-4.821$, $p<.001,95 \% \mathrm{CI}=-0.004,-0.002$, private and public respectively).

Moderation by medical specialty was also tested (Fig. 1). The interaction between sector and medical specialty had a significant effect on refusal of innovative treatments $(F$ $(11,595)=1.988, p=.035)$ (DV1) and shortages of drugs $(F(11,520)=4.206, p<.001)($ DV3) (Table 5).

There was a significant difference between the two sectors for refusal of innovative treatments in stomatology $(p=.024)$ and radiology $(p=.004)$. On the other hand, the answer "yes" was more frequent for oral

Table 4 Multivariate logistic regression model with the moderator effect of years of practice on quality of care

\begin{tabular}{|c|c|c|c|c|c|c|}
\hline & DV1 & DV2 & DV3 & DV4 & DV5 & DV6 \\
\hline \multirow[t]{2}{*}{ Exclusive in public ${ }^{a}$} & 1.556 & $1.160^{*}$ & -0.104 & -0.115 & -0.814 & 0.571 \\
\hline & $(0.857)$ & $(0.580)$ & $(0.714)$ & $(0.640)$ & $(0.710)$ & $(0.692)$ \\
\hline \multirow[t]{2}{*}{ Years of practice (exclusive in private) } & 0.002 & $-0.003^{* *}$ & $-0.005^{* *}$ & -0.002 & $-0.006^{* *}$ & 0.001 \\
\hline & $(0.002)$ & $(0.001)$ & $(0.002)$ & $(0.002)$ & $(0.002)$ & $(0.002)$ \\
\hline \multirow[t]{2}{*}{ Exclusive in public * Years of practice ${ }^{b}$} & $-0.005^{*}$ & 0.002 & 0.002 & 0.002 & $0.005^{* *}$ & $-0.004^{*}$ \\
\hline & $(0.002)$ & 0.001 & $(0.002)$ & $(0.002)$ & $(0.002)$ & $(0.002)$ \\
\hline \multirow[t]{2}{*}{ Constant } & $-2.742^{* *}$ & 0.212 & -0.229 & -0.775 & -0.522 & 0.172 \\
\hline & $(0.843)$ & $(0.563)$ & $(0.703)$ & $(0.626)$ & $(0.694)$ & $(0.645)$ \\
\hline Model $\mathrm{LL}=$ & $18.316^{* * *}$ & $186.426^{* * *}$ & $57.636^{* * *}$ & $13.628^{* *}$ & $52.207^{* * *}$ & $24.265^{* * *}$ \\
\hline \multicolumn{7}{|l|}{ Post hoc tests } \\
\hline \multirow[t]{2}{*}{ Years of practice (exclusive in public) } & $-0.003^{* * *}$ & $-0.002^{* *}$ & $-0.003^{* * *}$ & $-0.002^{* *}$ & -0.002 & 0.000 \\
\hline & $(0.001)$ & $(0.001)$ & $(0.002)$ & $(0.001)$ & $(0.001)$ & $(0.002)$ \\
\hline
\end{tabular}

Non-standardized coefficients and standard errors (in brackets) are reported

${ }^{a}$ Exclusive private (baseline)

bInteraction effect

${ }^{*} p<.05 ;{ }^{* *} p<.01 ;{ }^{* * *} p<.001$ 


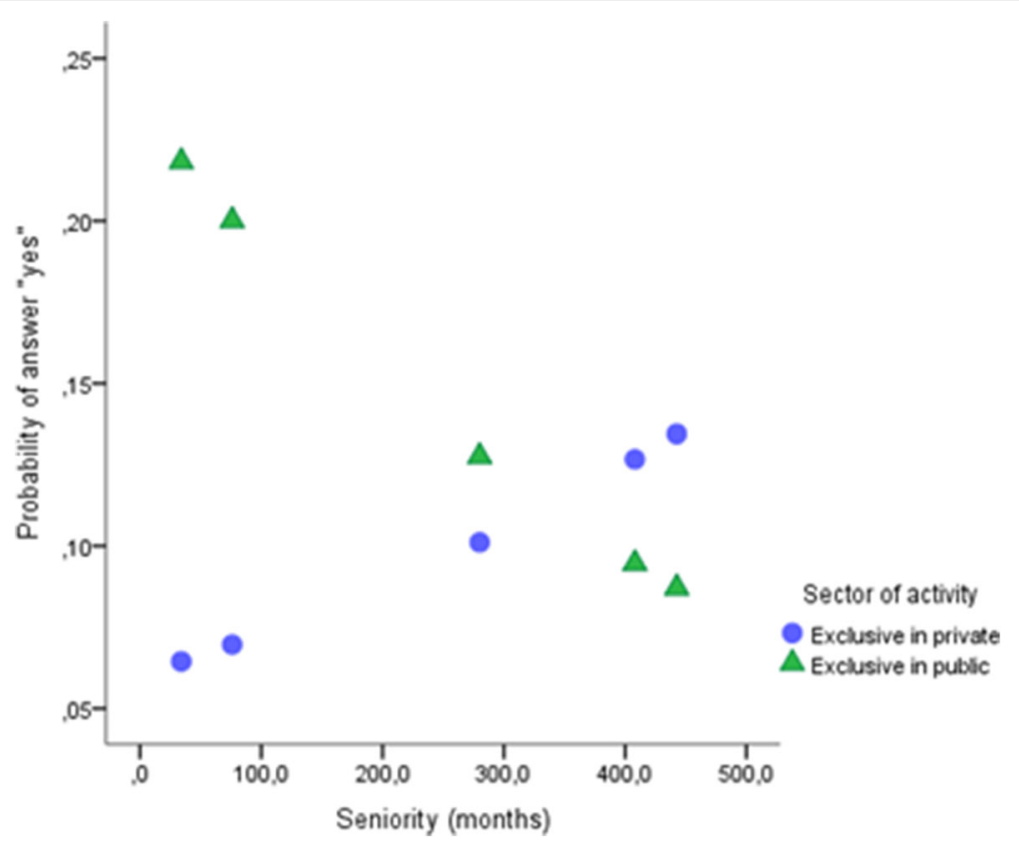

Fig. 2 Interaction between sector and years of practice in refusal of innovative treatments

medicine in the private sector and radiology in the public sector (Fig. 5). Shortages of drugs were significantly different between the sectors in various specialties: physical medicine and rehabilitation $(p=.001)$, internal medicine $(p=.020)$, general practice/family medicine $(p=.020)$, general surgery $(p=.006)$, ophthalmology $(p=.038)$, and psychiatry $(p<.001)$. With the exception of general practice/family medicine, the answer "yes" was more frequent in the public sector for all the other medical specialties (Fig. 6).

\section{Discussion}

The understanding of the effects of adjustment programs like those of Greece, Portugal, Ireland, and Cyprus fills an important gap in the literature on policy responses in Europe to the recent economic crisis. Conclusions result

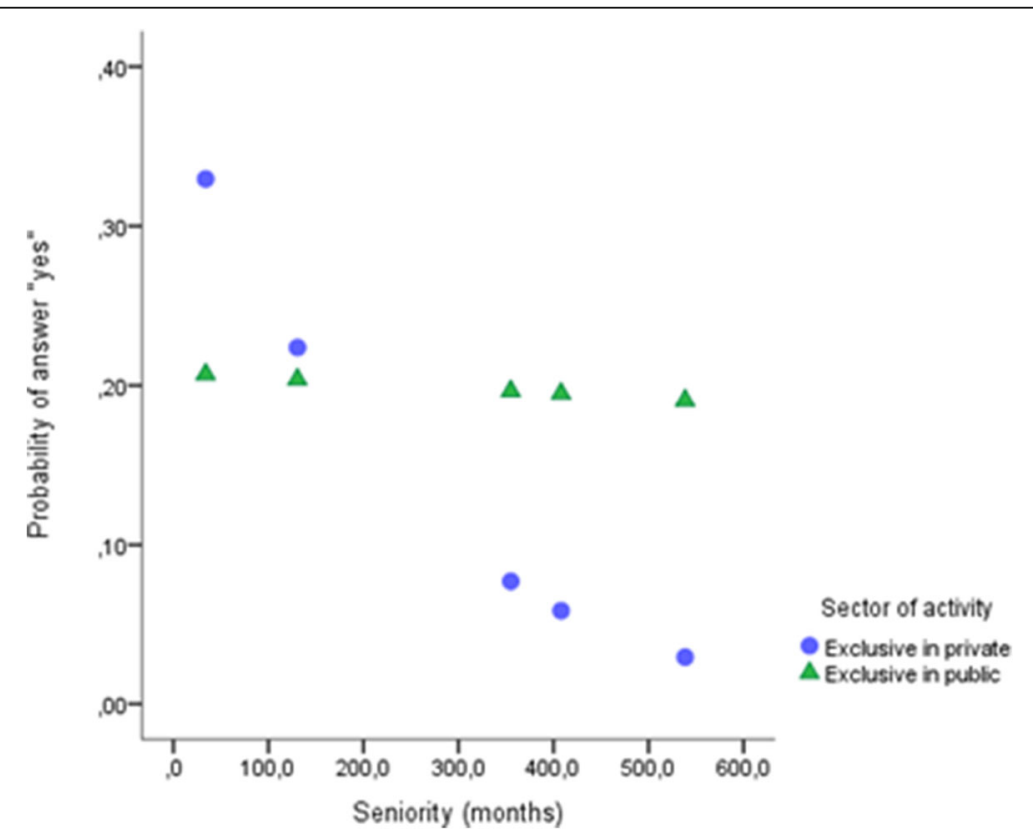

Fig. 3 Interaction between sector and years of practice in pressure not to prescribe certain drugs 


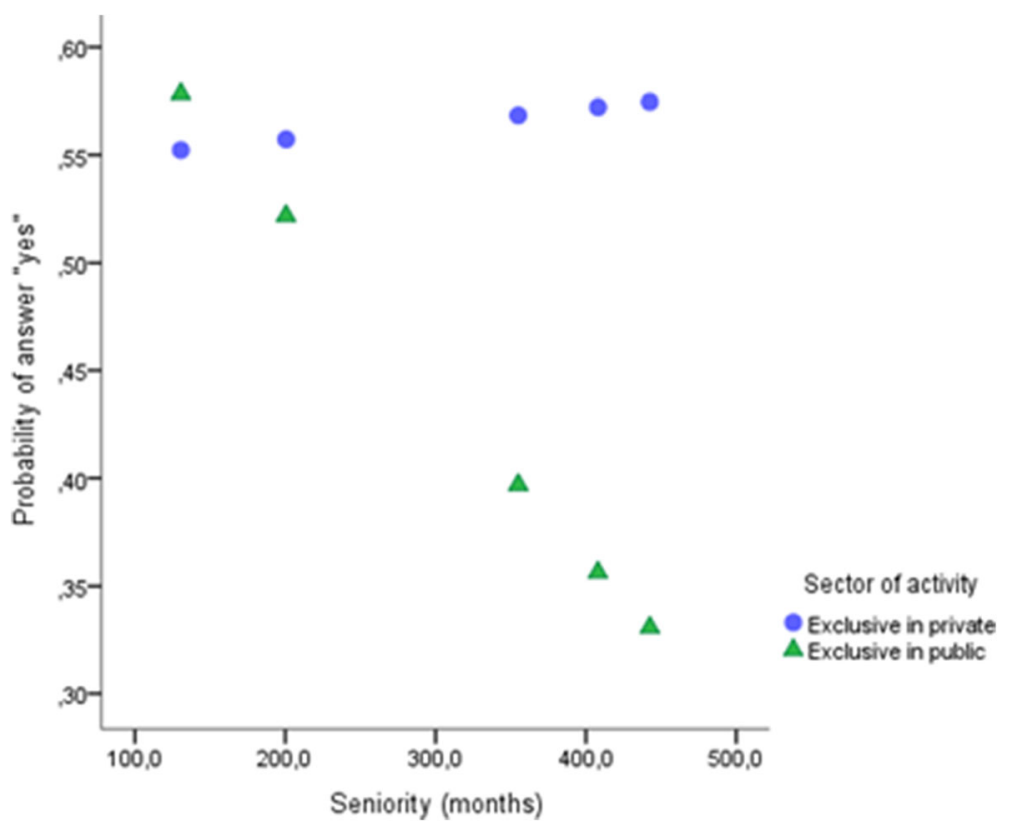

Fig. 4 Interaction between sector and years of practice in deterioration in medical training

in non-convergent evidence and therefore further analysis is required. The framework for this study was built on two overlooked assumptions. First, the understanding of the effects of the crisis on health systems performance is still limited given that few analyses have been conducted on quality of care as compared to efficiency and access. Second, looking at healthcare delivery is likely to reveal differences in relation to the analysis of planning or purchasing due to workplace-level contingencies. This led us to assess, based on the experience of those who provide care, whether structural reforms impacted the care delivery process and the quality of services.

Accordingly, we suggest that the reforms made under the Portuguese adjustment program had negative effects on the quality of care, namely in terms of shortages of work resources, less favorable conditions for medical residencies, and to a lesser extent, more administrative interference in clinical decisions. Reports of negative effects were consistently higher among physicians working exclusively for the NHS, which illustrates that the public sector was the main target of health-related austerity measures, even though these were expected to apply to all types of providers without exception.
Our findings show also that the austerity measures were felt differently in the public and private sectors. Results in the NHS suggest insufficient resources and greater constraints on physicians' individual decision-making (e.g., equipment shortages and administrative interference in clinical decisions). In the private sector, the main outcome of reforms was the negative impact on medical residencies due to overworked residents and to less time for tutors to provide training. Constraints in both sectors require further studies for a better understanding of its effects on clinical autonomy and training and ultimately on health outcomes.

Looking at public and private services, physicians in public hospitals reported more denials of innovative treatments, more drug shortages, and less favorable conditions for medical residencies. Primary care physicians reported more equipment shortages and administrative interference in medical decisions. In the private sector, physicians in small offices reported more refusals of innovative treatments than those in clinics and private hospitals, while the latter complained more deterioration in medical residency.

The argument that physicians' experiences depend on the sector of activity is reinforced when we analyzed the

Table 5 GLM Univariate Analysis with the moderator effect on the relationship between medical specialty and quality of care

\begin{tabular}{|c|c|c|c|c|c|c|}
\hline & DV1 & DV2 & DV3 & DV4 & DV5 & DV6 \\
\hline Sector & $F(1,595)=0.842$ & $F(1,609)=68.809^{* * *}$ & $F(1,520)=23.010^{* * *}$ & $F(1,606)=0.006$ & $F(1,764)=0.571$ & $F(1,382)=2.038$ \\
\hline Medical specialty & $F(11,595)=2.701^{* *}$ & $F(11,609)=3.447^{* * *}$ & $F(11,520)=0.898$ & $F(11,606)=1.130$ & $F(11,764)=1.143$ & $F(11,382)=0.927$ \\
\hline Interaction between sector and medical specialty & $F(11,595)=1.988^{*}$ & $F(11,609)=1.370$ & $F(11,520)=4.206^{* * *}$ & $F(11,606)=0.993$ & $F(11,764)=0.822$ & $F(11,382)=1.353$ \\
\hline
\end{tabular}




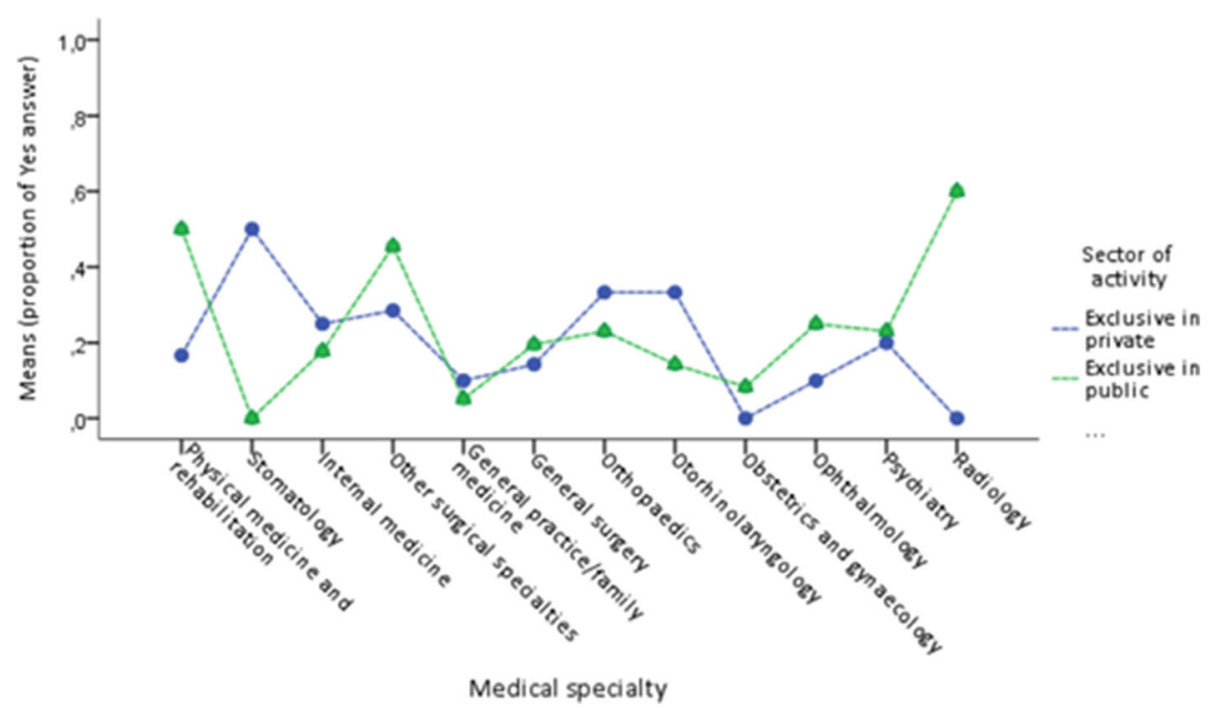

Fig. 5 Interaction between sector and medical specialty in refusal of innovative treatments

moderating effects of two key factors in medical hierarchy (years of practice and specialty). The reporting of denial of innovative treatments decreases with seniority in the public sector, while it increases in the private sector. Administrative interference was perceived as higher by less-experienced physicians in the private sector, while in the public sector years of service made no difference as to the pressure to limit the prescription of certain drugs. More less-experienced physicians in the public sector mentioned less favorable conditions for medical residencies, while this trend was not found in the private sector. As to differences between medical specialties, refusal of innovative treatments was more reported by stomatologists in the private sector than those in the public sector and by radiologists in the public sector than those in the private sector. Shortage of drugs was more reported by public-sector physiologists, internists, surgeons, ophthalmologists, and psychiatrists than by these specialists in the private sector, while general practitioners in the private sector reported it more than their colleagues in the NHS.

Our study shows that physicians in public and private sectors and within each sector have different perceptions, depending on their specific characteristics, of the impact of the same policy responses.

A number of potential long-term effects that this empirical study cannot address are associated with these results. One in particular is here uncovered to highlight possible

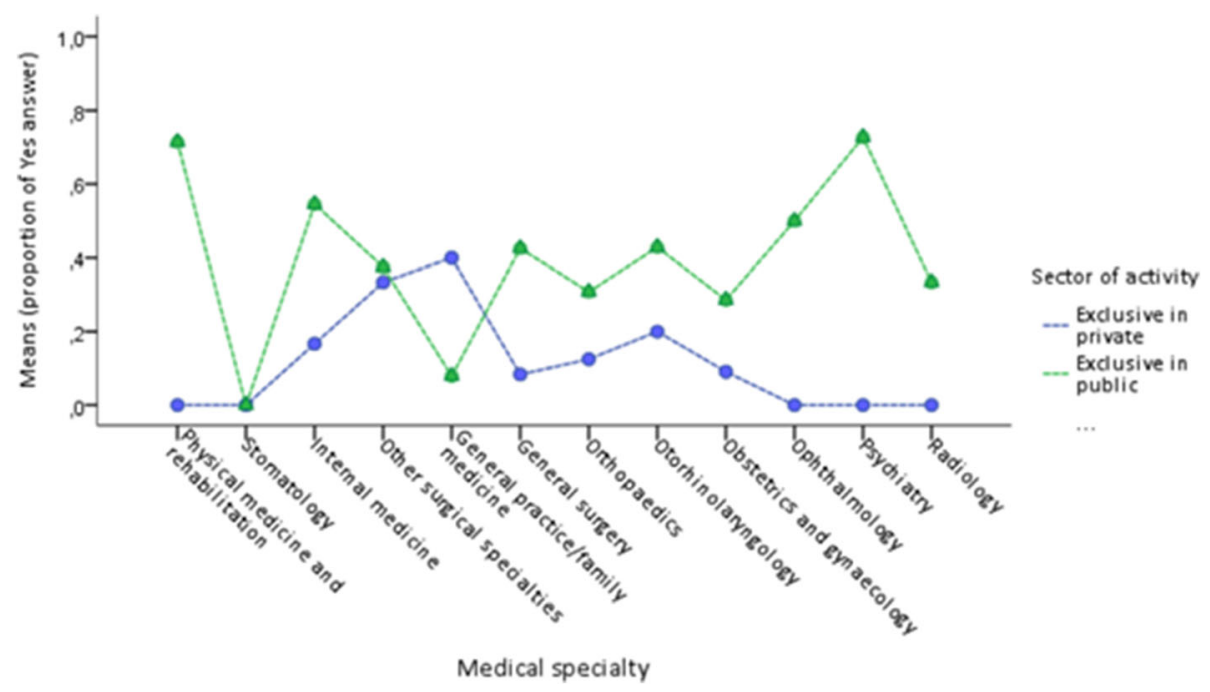

Fig. $\mathbf{6}$ Interaction between sector activity and medical specialty on shortage of drugs 
directions for research. Lower quality healthcare services presumably affect health professionals' and patients' individual choices. Given that the influence of trust in individuals' decisions is well understood [23, 24], the understudied link is the effects of lower quality on the undermining of trust relationships in health. The issue is to know how lower quality affect professionals' and patients' individual choices and whether these choices can affect health systems structurally.

As to the NHS, the quality-trust link builds on the moral contract between authorities, citizens, and professionals. Professionals feeling that they are not being given the conditions they need for their work and patients questioning the need for higher taxation to fund access to services that are less trustworthy can translate into the growth of the private market in parallel to the public sector. As to the private sector, the quality-trust link is a key element in market competition. Greater pressure is put on the supply side in investment in communication strategies and patient-centered care approaches. Consequently, it is relevant to discuss possible increases in households' spending and growing exposure to deregulation of the health labor market.

\section{Limitations}

We were unable to establish the representativeness of the respondents, even though the total number of over 3000 is high. Also, the instrument does not permit a clear assessment of the moderating effect of physicians' years of practice and specialties, selected as proxy of internal stratification of the medical profession. More empirical in-depth research into this issue is needed. Lastly, the measurements of quality of care delivery reflect physicians' personal experiences and views and are therefore not comparable to those of health workers.

\section{Conclusion}

The aim of this article was to add to the understanding of the effects of policy responses to the 2008 crisis on health system performance in Europe. In Portugal, there is an institutional discourse that the health system adapted well to cost containment [25]. By focusing on the perceptions of professionals of the effects of the crisis on their work and on the quality of care, we offer a complementary contribution. Also, our findings show that the outcomes of policy responses may not have been the same in all national health care systems, therefore requiring context-sensitive analyses.

The added value of an analysis built on a macro (political)-micro (organizational) link is likely to reveal a different reality from that showed by general statistics, which do not reflect concrete experiences. It also shows the non-linearity between policy setting and expected outcomes, which is particularly relevant in assessing the effects of austerity measures. The fact that only physicians were surveyed and the lack of standardized data on physicians in Portugal are limitations that further research can help mitigate.

\section{Abbreviations \\ DV: Dependent variable; MoU: Memorandum of Understanding; NHS: National Health Service}

\section{Acknowledgements}

This article is a partial outcome of broad scientific collaboration between a research team at the University Institute of Lisbon, coordinated by Dr. Tiago Correia, and the Portuguese Medical Council, with the aim of studying the effects of the adjustment program on physicians. We are very grateful to all the physicians who agreed to participate in the study and to Joana Vieira for helping collect some institutional information.

\section{Funding}

TC holds a research grant funded by FCT [SFRH/BPD/84175/2012]. No additional funding was received for this study.

\section{Availability of data and materials}

The datasets generated and/or analyzed during the current study are not publicly available due to the ethics approval by the Portuguese Medical

Council's ethics committee.

\section{Authors' contributions}

TC had the idea for the paper, developed the conceptual approach, wrote the first draft, and revised the manuscript. GC participated in the development of the conceptual approach and revised the first draft of the manuscript. HC developed the data analysis and co-wrote parts of the manuscript. JMS created the tool of data collection and coordinated the process of data gathering. GD participated in the development of the conceptual approach and revised the second draft of the manuscript. All authors read and approved the final manuscript.

\section{Ethics approval and consent to participate}

The authors hereby declare that (1) the content of the questionnaire, (2) the storage in paper format and digital records, and (3) data analysis received the approval by the Portuguese Medical Council's ethics committee.

\section{Consent for publication}

Not applicable.

\section{Competing interests}

$T C, G C, H C$, and GD declare that they have no competing interests. JMS was at the time of the study President of the Portuguese Medical Council.

\section{Publisher's Note}

Springer Nature remains neutral with regard to jurisdictional claims in published maps and institutional affiliations.

\section{Author details}

${ }^{1}$ School of Sociology and Public Policies, ISCTE-Instituto Universitário de Lisboa, Av Forcas Armadas, 1649-026 Lisbon, Portugal. ²Portuguese Medical Council, Av Almirante Gago Coutinho, 151, 1749-084 Lisbon, Portugal. ${ }^{3}$ Global Health and Tropical Medicine, WHO Collaborating Center on Health Workforce Policy and Planning, Instituto de Higiene e Medicina Tropical, Universidade Nova de Lisboa, Rua da Junqueira, 100, 1349-008 Lisbon, Portugal.

Received: 14 March 2017 Accepted: 28 November 2017 Published online: 12 December 2017

\section{References}

1. Thomson S, Figueras J, Evetovits T, Jowett M, Mladovsky P, Maresso A, Cylus J, Karanikolos M, Kluge H. Economic crisis, health systems and health in Europe: impact and implications for policy. WHO Regional Office for Europe: Copenhagen; 2014. 
2. Kuhlmann E, Batenburg R, Dussault G. Health workforce governance in Europe: where are we going? Health Policy. 2015;119(12):1515-6.

3. WHO Regional Office for Europe. Health in times of global economic crisis: implications for the WHO European region - overview of the situation in the WHO European region. Copenhagen: WHO Regional Office for Europe; 2009.

4. Mladovsky P, Srivastava D, Cylus J, Karanikolos M, Evetovits T, Thomson S, McKee M. Health policy responses to the financial crisis in Europe-policy summary 5. WHO Regional Office for Europe: Copenhagen; 2012.

5. Scott R. Lords of the dance: Professionals as institutional agents. Organisation Studies. 2008;29(2):219-38.

6. Koelewijn WT, de Rover M, Ehrenhard ML, van Harten WH. Physician entrepreneurship explained: a case study of intra-organizational dynamics in Dutch hospitals and specialty clinics. Hum Resour Health. 2014;12:28.

7. Correia T, Denis J-L. Hybrid management, organizational configuration, and medical professionalism: evidence from the establishment of a clinical directorate in Portugal. BMC Health Services Research. 2016;16:161.

8. Numerato $D$, Salvatore $D$, Fattore $G$. The impact of management on medical professionalism: a review. Sociol Health IIIn. 2012;34(4):626-44.

9. McDonald R. Restratification revisited: The changing landscape of primary medical care in England and California. Curr Sociol. 2012;60(4):441-55.

10. Correia T. Doctors' reflexivity in hospital organisations: the nexus between institutional and behavioural dynamics in the sociology of professions. Curr Sociol. 2017;65(7):1050-69.

11. Greer S, Hervey T, Mackenbach J, McKee M. Health law and policy in the European Union. The Lancet. 2013;381(9872):1135-44.

12. Nishtar S, The mixed health systems syndrome. Bulletin of the World Health Organization. 2010;88(1):66-73.

13. European Commission. The economic adjustment programme for Portugal. Occasional papers 79. European Commission: Brussels; 2011.

14. European Commission. The economic adjustment programme for Portugal, eleventh review. Occasional papers 191. European Commission: Brussels; 2014.

15. Sakellarides C, Castelo-Branco L, Barbosa P, Azevedo H. The impact of the financial crisis on the health system and health in Portugal. European Observatory on Health Systems and Policies: Copenhagen; 2014.

16. Temido M, Dussault G. How can a country learn from the experience of another? Expanding nurses' scope of practice in Portugal: lessons from England. Health Policy. 2014;1 19(4):475-87.

17. Correia $T$, Dussault $G$, Pontes $C$. The impact of the financial crisis on human resources for health policies in three southern-Europe countries. Health Policy. 2015;119(12):1600-5.

18. Lagarde M, Blaauw DA. Review of the application and contribution of discrete choice experiments to inform human resources policy interventions. Hum Resour Health. 2009;7:62.

19. Campbell S, Roland M, Buetow S. Defining quality of care. Soc Sci Med. 2000;51(11):1611-25.

20. Donabedian A. The quality of care: how can it be assessed? JAMA 1988;206(12):1743-8.

21. Hayes H. Introduction to mediation, moderation, and conditional process analysis: a regression-based approach. New York: Guilford Press; 2013.

22. Aiken L, Stephen G. Multiple regression: testing and interpreting interactions. Newbury Park: Sage; 1991.

23. Rowe R, Calnan M. Trust relations in health care: the new agenda. The European Journal of Public Health. 2006;16(1):4-6.

24. Okello DRO, Gilson L. Exploring the influence of trust relationships on motivation in the health sector: a systematic review. Hum Resour Health. 2015;13:16

25. OECD. OECD reviews of health care quality: Portugal 2015. Paris: OECD; 2015.

26. European Commission. The economic adjustment programme for Portugal 2011-2014. Occasional papers 202. Brussels: European Commission. p. 2014.

27. Government of Portugal. Technical memorandum of understanding Portugal: Government of Portugal; 2011.

\section{Submit your next manuscript to BioMed Central and we will help you at every step:}

- We accept pre-submission inquiries

- Our selector tool helps you to find the most relevant journal

- We provide round the clock customer support

- Convenient online submission

- Thorough peer review

- Inclusion in PubMed and all major indexing services

- Maximum visibility for your research

Submit your manuscript at www.biomedcentral.com/submit
Biomed Central 